\title{
Allelopathic Activity of Spearmint (Mentha spicata L.) and Peppermint (Mentha $\times$ piperita L.) Reduces Yield, Growth, and Photosynthetic Rate in a Succeeding Crop of Maize (Zea mays L.)
}

\author{
Anestis Karkanis *(D), Alexandros Alexiou, Christos Katsaros and Spyridon Petropoulos *(D) \\ Department of Agriculture Crop Production and Rural Environment, University of Thessaly, Fytokou Street, \\ 38446 Volos, Greece \\ * Correspondence: akarkanis@uth.gr (A.K.); spetropoulos@uth.gr (S.P.); \\ Tel.: +30-2421-093-135 (A.K.); +30-2421-093-196 (S.P.)
}

Received: 21 July 2019; Accepted: 14 August 2019; Published: 16 August 2019

check for updates

\begin{abstract}
The inclusion of species with allelopathic activity in crop rotation systems may have benefits for crop management such as weed control, but less is understood about their wider impacts on succeeding crops. The main objective of this study was to investigate the effects of two allelopathic species (spearmint and peppermint) on growth, physiological characteristics, and yield of a following maize crop. Thus, field experiments were carried out at two sites, according to a randomized complete block design, while the examined treatments were: (a) fallow-fallow-maize crop rotation system (FFM), (b) spearmint-spearmint-maize crop rotation system (SSM), and (c) peppermint-peppermint-maize crop rotation system (PPM). Our results indicated that the inclusion of spearmint or peppermint in crop rotation systems negatively affect the growth of maize plants. The highest plant height was recorded for FFM rotation system where no allelopathic species were used. At both sites and for four sampling dates, the aboveground dry biomass was also affected by the implemented crop rotation system. In particular, dry biomass was significantly lower in the PPM and SSM crop rotation systems comparing to the FFM system, whereas there were no significant differences between these two crop rotation systems. Similar to the maize biomass, the highest values of photosynthetic rate, stomatal conductance, and relative chlorophyll content were observed for the FFM rotation system. Additionally, differences in grain yield were observed among the tested crop rotation systems. Grain yield ranged from 10,200 to 13,346 kg ha-1 and from 11,773 to $14,106 \mathrm{~kg} \mathrm{ha}^{-1}$ at site A and B, respectively, while it was reduced by $16.54-23.58 \%$ and $12.16-17.83 \%$ in the SSP and PPM rotation systems comparing to the FFM system. In conclusion, our results indicate that the inclusion of peppermint or spearmint in crop rotation may inhibit plant growth and reduce grain yield of maize as successive crop, an effect that could be attributed to the allelopathic activity of spearmint and peppermint.
\end{abstract}

Keywords: allelopathy; aromatic plants; crop rotation; cultural practices; grain yield; maize; Mentha $\times$ piperita L.; Mentha spicata L.; peppermint; spearmint

\section{Introduction}

The design and length of a crop rotation is of prime importance for maintaining crop productivity at a high level through environmentally friendly and sustainable cultural practice. In order to have positive effects on crop production it is necessary to properly design the crop rotation systems following basic principles and rules [1]. For example, the inclusion of legumes such as cowpea, faba bean, 
pea, and soybean in crop rotation systems improves soil fertility [2-5] and increases crop yields $[4,6]$, while it also reduces the need for application of nitrogen fertilizers on successive crops [3,7].

A properly designed crop rotation system may also help to control weeds and diseases, thus reducing the agrochemical inputs which is pivotal in organic farming systems [1,8-10]. The inclusion of crops with allelopathic potential in a crop rotation system can significantly reduce the weed pressure on crops [11-15] due to the release of various secondary metabolites also known as allelochemicals [14]. In this context, Rehman et al. [15] reported that Brassica species can be included in crop rotation systems or can be used for mulching and as cover crops for weed control, since they produce allelochemicals such as glucosinolates, brassinosteroids, and allyl isothiocyanates which show phytotoxic effects against to targeted species including weeds. In another study, Farooq et al. [16] observed that the dry weight and density of weeds in a rice crop was reduced by $77 \%$ and $78 \%$, respectively, when sorghum water extracts and sorghum mulch were implemented in a crop rotation system of wheat-sorghum-dry seeded aerobic rice (DSAR) in comparison to wheat-fallow-DSAR cultivation system. Additionally, Liu et al. [17] found that tomato yield was increased when rotated with Chinese onion (Allium cepa L. var. aggregatum G. Don), while at the same time the incidence of Fusarium wilt (Fusarium oxysporum f.sp. lycopersici (Sacc.) Snyder \& Hansen) was reduced due to the allelopathic potential of root exudates of Chinese onion. The efficacy of Labiatae species for weed control has been also reported by Mominul Islam and Kato-Noguchi [18] who observed significant inhibitory effects of aqueous methanol extracts from five Labiatae species against barnyard grass (Echinochloa crus-galli (L.) P. Beauv.).

Peppermint (Mentha $\times$ piperita L.) and spearmint (Mentha spicata L.) are perennial aromatic plants cultivated worldwide [19], while both crops as well as other Mentha species exhibit allelopathic activity against weeds through their plant extracts or essential oils [20-24]. However, despite the positive effects of Mentha crops on weed control, their negative effects on plant growth and yield of crops has been observed. In particular, Argyropoulos et al. [20] reported a negative effect on seed germination and seedling length for Mentha spicata essential oils not only in the case of weeds but also for tomato and cotton crops, while similar results have been reported for Mentha $\times$ piperita water extracts on tomato seeds germination and seedling growth. In contrast, Chalkos et al. [23] reported that incorporating Mentha spicata composts in growth media at various rates $(0-8 \% w / w)$ significantly increased tomato growth while inhibited weed emergence at the same time. In another study, Naeem et al. [25] observed that rapeseed (Brassica napus L.) retarded the growth of maize seedlings, although the negative effects diminished at high salinity levels.

To the best of our knowledge, a limited number of studies have been published regarding the effects of spearmint and peppermint on growth and yield of succeeding crops in crop rotation systems. Considering the wide-spread cultivation of both species worldwide it is essential to obtain information about the crops that are susceptible to allelopathic effects in order to design proper rotation programs in sustainable cultivation systems. The experimental hypothesis was to test whether the selected allelopathic species (spearmint and peppermint) had a positive, negative, or no effect on agronomic and physiological parameters of maize. For this purpose, spearmint and peppermint were included in a crop rotation system with maize in order to evaluate their effect on the growth, physiological characteristics, and yield of maize crop. These results will be of practical use for farmers in order to (a) properly design a crop rotation system in farms where spearmint and peppermint are cultivated and (b) minimize the negative effects on successive crops production.

\section{Materials and Methods}

\subsection{Study Site}

Two field experiments were carried out: (A) at the experimental farm of the University of Thessaly in Velestino (22.756 E, $39.396 \mathrm{~N}$; site A) and (B) at Domokos region in Central Greece (22.336 E, 39.036 N; site B). The soil of site A was sandy clay loam in texture (clay: $26 \%$, silt: $36 \%$, and sand: $38 \%$ ) with 
a pH of 7.4 , while the soil of site B was clay (clay: $50.7 \%$ clay, silt: $23.3 \%$, and sand: $26 \%$ ) with $\mathrm{pH}$ 7.6. Total precipitation during the growing season was $171.7 \mathrm{~mm}$ and $409.4 \mathrm{~mm}$ at site A and site $\mathrm{B}$, respectively.

\subsection{Experimental Design}

Spearmint and peppermint crops were established by hand using rhizomes (70 cm (rows distance) $\times 40 \mathrm{~cm}$ (within row distance)) on 7 May 2014 and 3 May 2015 at site A and B, respectively. The size of each plot was $21 \mathrm{~m}^{2}(3 \times 7 \mathrm{~m})$. At each experimental site, plots of the same size remained fallow to be used as control treatments. Spearmint and peppermint plants were cultivated for two consecutive growing periods. At the end of the second growing period and after the final harvest the field was ploughed at the depth of $30 \mathrm{~cm}$. Maize (Zea mays cv. P1547 F1) was sown on the 19 April 2016, and 15 April 2017, at site A and site B, respectively. Seeds were sown using a pneumatic sowing machine at a depth of $3 \mathrm{~cm}$, in rows $75 \mathrm{~cm}$ apart, while the distance within the rows was $16 \mathrm{~cm}$. The experimental design was a randomized complete block design with three treatments and three replications. The three treatments of the experiments were (a) fallow-fallow-maize rotation system (FFM), (b) spearmint-spearmint-maize rotation system (SSM), and (c) peppermint-peppermint-maize rotation system (PPM).

Regarding the cultivation practices in maize crop, the inorganic fertilizer $15-15-15(+5 \% \mathrm{~S})$ was applied as base dressing $\left(300 \mathrm{~kg} \mathrm{ha}^{-1}\right)$, while at 30 DAS (days after sowing) and 50 DAS ammonium nitrate (34.5-0-0) was applied at a rate of $20 \mathrm{~kg} \mathrm{ha}^{-1}$. In order to avoid the weed competition three hand hoeing's were applied at 25 DAS, 40 DAS, and 55 DAS. Moreover, after the maize sowing the experimental fields were irrigated using a sprinkler irrigation system. Then, a drip irrigation system was set up in each row, while the irrigation intervals depended on temperature and ranged from 4 to 7 days.

\subsection{Sampling, Measurements, and Methods}

\subsubsection{Agronomic Parameters}

Plant height and dry weight of maize was measured at 40 DAS, 70 DAS, 84 DAS, and 98 DAS. These measurements were recorded at 5 maize plants randomly selected from each treatment and replication ( 45 plants in total). The dry biomass was determined after drying plant samples at $60^{\circ} \mathrm{C}$ for $96 \mathrm{~h}$. For grain yield determination, 10 maize plants were harvested from each treatment and replicated (90 plants in total) on 5 October 2016, and 21 October 2017, at site A and site B, respectively. Also, ear length and 1000-grain weight $(3 \times 100$ grains $)$ were measured at the day of harvest.

\subsubsection{Physiological Parameters}

Physiological parameters (photosynthetic rate, stomatal conductance, and chlorophyll content) measurements were also recorded. Photosynthetic rate and stomatal conductance were recorded between 11:00 a.m. and 14:00 p.m. with the Portable Photosynthesis System LI-6400 (LI-COR Biosciences, Inc., Lincoln, NE, USA) at 84 DAS, while the relative chlorophyll content (SPAD index values) was also determined using a handheld SPAD-502 chlorophyll meter (Konica Minolta Optics, Inc., Osaka, Japan) at 40 DAS, 70 DAS, 84 DAS, and 98 DAS in both sites.

\subsection{Statistical Analysis}

For each experimental site, the data were subjected to statistical analysis according to a randomized complete block (RCB) design. Firstly, an analysis of variance (ANOVA) was carried out, while means were compared using a Fisher's Least Significant Difference test (LSD, $p \leq 0.05$ ) when ANOVA was significant at $p \leq 0.05$. Finally, a Pearson's correlation analysis was used to examine the relationships between the studied maize characteristics. For statistical analyses, the SigmaPlot 12 statistical package (Systat Software, San Jose, CA, USA) was used. 


\section{Results}

\subsection{Physiological Parameters}

Differences in relative chlorophyll content (SPAD index values) were recorded among the tested rotation systems at both experimental sites (Table 1). At both sites and for all the sampling dates, the relative chlorophyll content was influenced by the rotation system, except for the case of the last sampling date (98 DAS) at experimental site B where no significant differences were observed. In particular, SPAD index values were significantly lower in the PPM and SSM rotation systems regardless of sampling date, whereas there were no significant differences between these two systems. Moreover, chlorosis of leaves was observed on maize plants in the PPM and SSM rotation systems, indicating possible toxic effects or stressful conditions for plant growth. At the final measurement (98 DAS) in experimental site A, the SPAD index values ranged from 44.72 to 55.90 exhibiting a reduction by $18.30 \%$ and $20.00 \%$ in the SSP and PPM rotation systems in comparison to the FFM system. Similarly, SPAD index values at site B were greater in the FFM rotation system, although no significant differences among the tested systems were observed at the final sampling date (98 DAS).

Table 1. Relative chlorophyll content (SPAD index values) of maize leaves as affected by the rotation system (fallow-fallow-maize (FFM), spearmint-spearmint-maize (SSM), peppermint-peppermint-maize (PPM)) at experimental sites A and B. Means at the same column followed by the same letter are not significantly different according to Fisher's Least Significant Difference (LSD) test $(p \leq 0.05)$.

\begin{tabular}{|c|c|c|c|c|}
\hline \multirow{2}{*}{ Treatments-Rotation System } & \multicolumn{4}{|c|}{ SPAD Index Values-Site A } \\
\hline & 40 DAS $^{1}$ & 70 DAS & 84 DAS & 98 DAS \\
\hline fallow-fallow-maize (FFM) & $42.94 \mathrm{a}$ & $54.90 \mathrm{a}$ & $56.80 \mathrm{a}$ & $55.90 \mathrm{a}$ \\
\hline spearmint-spearmint-maize (SSM) & $25.63 \mathrm{~b}$ & $34.97 \mathrm{~b}$ & $46.63 \mathrm{~b}$ & $45.67 \mathrm{~b}$ \\
\hline peppermint-peppermint-maize (PPM) & $27.27 b$ & $33.49 \mathrm{~b}$ & $49.54 \mathrm{~b}$ & $44.72 \mathrm{~b}$ \\
\hline F values & $240.558^{* * *}$ & $43.202 * *$ & $159.477 *$ & $40.680 * *$ \\
\hline $\mathrm{LSD}_{5 \%}$ & 2.418 & 7.143 & 1.628 & 3.816 \\
\hline \multirow{2}{*}{ Treatments-Rotation System } & \multicolumn{4}{|c|}{ SPAD Index Values-Site B } \\
\hline & 40 DAS & 70 DAS & 84 DAS & 98 DAS \\
\hline fallow-fallow-maize (FFM) & $45.26 \mathrm{a}$ & $52.00 \mathrm{a}$ & $53.56 \mathrm{a}$ & $52.97 \mathrm{a}$ \\
\hline spearmint-spearmint-maize (SSM) & $34.99 \mathrm{~b}$ & $41.53 \mathrm{~b}$ & $48.33 \mathrm{~b}$ & $51.85 \mathrm{a}$ \\
\hline peppermint-peppermint-maize (PPM) & $37.08 \mathrm{~b}$ & $44.07 \mathrm{~b}$ & $47.80 \mathrm{~b}$ & $53.68 \mathrm{a}$ \\
\hline F values & $19.132 * *$ & $90.054 * * *$ & $12.025 *$ & $2.138^{\mathrm{ns}}$ \\
\hline $\mathrm{LSD}_{5} \%$ & 4.871 & 2.259 & 3.602 & - \\
\hline
\end{tabular}

The photosynthetic rate ranged from 24.67 to $35.53 \mu \mathrm{mol} \mathrm{CO} \mathrm{C}^{-2} \mathrm{~s}^{-1}$ and from 27.70 to $34.30 \mu \mathrm{mol}$ $\mathrm{CO}_{2} \mathrm{~m}^{-2} \mathrm{~s}^{-1}$ at sites $\mathrm{A}$ and $\mathrm{B}$, respectively (Table 2). Differences in photosynthetic rate were also observed among the rotation systems at both sites. The lowest values of this parameter were recorded for the PPM and SSM rotation systems revealing the possible allelopathic activity of spearmint and peppermint against maize plants. At site A, photosynthetic rate of maize plants was reduced by $30.57 \%$ and $27.30 \%$ in the SSM and PPM rotation systems, respectively, in comparison to FFM system. Similar results were observed at site B where photosynthetic rate was reduced by $16.53 \%$ and $19.24 \%$ in the SSM and PPM rotation systems in comparison to FFM system.

The stomatal conductance was also influenced by the implemented rotation system. Our data revealed that stomatal conductance at 84 DAS was significantly lower in the SSM and PPM rotation system than in the FFM system at both sites. Moreover, at site A, the stomatal conductance was reduced by $40.82 \%$ and $32.65 \%$ in the SSM and PPM rotation systems, respectively comparing to the FFM 
system, while at site B the negative effects of SSM and PPM rotation systems on stomatal conductance were slightly lower (reduction by $26.41 \%$ and $30.19 \%$ for SSM and PPM, respectively).

Table 2. Photosynthetic rate $\left(\mu \mathrm{mol} \mathrm{CO} \mathrm{CO}^{-2} \mathrm{~s}^{-1}\right)$ and stomatal conductance $\left(\mathrm{mol} \mathrm{H}_{2} \mathrm{O} \mathrm{m}^{-2} \mathrm{~s}^{-1}\right)$ of maize plants at 84 days after sowing as affected by the rotation system (fallow-fallow-maize (FFM), spearmint-spearmint-maize (SSM), peppermint-peppermint-maize (PPM)) at experimental sites A and B. Means at the same column followed by the same letter are not significantly different according to Fisher's Least Significant Difference (LSD) test $(p \leq 0.05)$.

\begin{tabular}{|c|c|c|}
\hline \multirow[b]{2}{*}{ Treatments-Rotation System } & \multicolumn{2}{|c|}{ Site A } \\
\hline & $\begin{array}{l}\text { Photosynthetic Rate } \\
\left(\mu \mathrm{mol} \mathrm{CO} \mathrm{C}^{-2} \mathrm{~s}^{-1}\right)\end{array}$ & $\begin{array}{l}\text { Stomatal Conductance } \\
\left(\mathrm{mol} \mathrm{H}_{2} \mathrm{O} \mathrm{m}^{-2} \mathrm{~s}^{-1}\right)\end{array}$ \\
\hline fallow-fallow-maize (FFM) & $35.53 \mathrm{a}$ & $0.49 \mathrm{a}$ \\
\hline spearmint-spearmint-maize (SSM) & $24.67 \mathrm{~b}$ & $0.29 \mathrm{~b}$ \\
\hline peppermint-peppermint-maize (PPM) & $25.83 \mathrm{~b}$ & $0.33 \mathrm{~b}$ \\
\hline$F$ values & $42.831^{* *}$ & $40.628^{* *}$ \\
\hline $\mathrm{LSD}_{5 \%}$ & 3.579 & 0.066 \\
\hline \multirow[b]{2}{*}{ Treatments-Rotation System } & \multicolumn{2}{|c|}{ Site B } \\
\hline & $\begin{array}{l}\text { Photosynthetic Rate } \\
\left(\mu \mathrm{mol} \mathrm{CO} \mathrm{m}^{-2} \mathrm{~s}^{-1}\right)\end{array}$ & $\begin{array}{l}\text { Stomatal Conductance } \\
\left(\mathrm{mol} \mathrm{H}_{2} \mathrm{O} \mathrm{m}^{-2} \mathrm{~s}^{-1}\right)\end{array}$ \\
\hline fallow-fallow-maize (FFM) & $34.30 \mathrm{a}$ & $0.53 \mathrm{a}$ \\
\hline spearmint-spearmint-maize (SSM) & $28.63 \mathrm{~b}$ & $0.39 \mathrm{~b}$ \\
\hline peppermint-peppermint-maize (PPM) & $27.70 \mathrm{~b}$ & $0.37 \mathrm{~b}$ \\
\hline$F$ values & $57.026^{* * *}$ & $62.384^{* * *}$ \\
\hline $\mathrm{LSD}_{5 \%}$ & 1.857 & 0.043 \\
\hline
\end{tabular}

\subsection{Maize Growth}

At experimental site A, maize height was influenced by the applied crop rotation system (Table 3). In particular, plant height was significantly lower in the PPM and SSM rotation systems, while there were no significant differences between these systems. At the final measurement (98 DAS), plant height ranged from 2.18 to $2.73 \mathrm{~m}$ with a significant reduction by $16.48 \%$ and $20.14 \%$ in the SSP and PPM rotation systems being observed in comparison to the FFM system. Similarly, at experimental site $B$ height of maize plants was negatively affected by the inclusion of peppermint and spearmint in the crop rotation system only at mid to late growth stages (70 and 84 DAS), whereas at 98 DAS plant height ranged between 2.21 and $2.44 \mathrm{~m}$, without however any significant differences between the crop rotation systems being observed.

At both experimental sites and for four sampling dates the aboveground dry biomass was also affected by the implemented rotation systems (Table 4). Dry biomass was significantly lower in the PPM and SSM rotation systems comparing to control treatment (FFM), whereas there were no significant differences between PPM and SSM for all the sampling dates. Moreover, at the final measurement, dry biomass ranged from 15,297 to $21,702 \mathrm{~kg} \mathrm{ha}^{-1}$ and from 16,837 to $19,844 \mathrm{~kg} \mathrm{ha}^{-1}$ at experimental sites A and B, respectively. At site A, the dry biomass was reduced by $29.51 \%$ and $25.12 \%$ in the SSM and PPM rotation systems in comparison to FFM system, while at experimental site B the negative effects of SSM and PPM rotation systems on dry biomass were slightly lower (15.15\% and 13.13\%, respectively). The reduction of both maize height and dry biomass in the SSP and PPM rotation system revealed the allelopathic activity of spearmint and peppermint on maize growth. However, the differences between experimental sites indicate the combinatory effect of growing conditions and allelopathic properties of Mentha species although it can be assumed that growing conditions play a key role on plant morphological parameters and plant height in this case. 
Table 3. Height (m) of maize plants as affected by the rotation system (fallow-fallow-maize (FFM), spearmint-spearmint-maize (SSM), peppermint-peppermint-maize (PPM)) at experimental site A and B. Means at the same column followed by the same letter are not significantly different according to Fisher's Least Significant Difference (LSD) test $(p \leq 0.05)$.

\begin{tabular}{|c|c|c|c|c|}
\hline \multirow{2}{*}{ Treatments-Rotation System } & \multicolumn{4}{|c|}{ Height (m)-Site A } \\
\hline & 40 DAS $^{1}$ & 70 DAS & 84 DAS & 98 DAS \\
\hline fallow-fallow-maize (FFM) & $0.52 \mathrm{a}$ & $1.76 \mathrm{a}$ & $2.42 \mathrm{a}$ & $2.73 \mathrm{a}$ \\
\hline spearmint-spearmint-maize (SSM) & $0.36 \mathrm{~b}$ & $1.42 \mathrm{~b}$ & $2.07 \mathrm{~b}$ & $2.28 \mathrm{~b}$ \\
\hline peppermint-peppermint-maize (PPM) & $0.39 \mathrm{~b}$ & $1.46 \mathrm{~b}$ & $2.03 \mathrm{~b}$ & $2.18 \mathrm{~b}$ \\
\hline$F$ values & $29.463^{* *}$ & $16.824 *$ & $9.111 *$ & $96.118^{* * *}$ \\
\hline $\mathrm{LSD}_{5 \%}$ & 0.059 & 0.180 & 0.279 & 0.117 \\
\hline \multirow{2}{*}{ Treatments-Rotation System } & \multicolumn{4}{|c|}{ Height (m)-Site B } \\
\hline & 40 DAS & 70 DAS & 84 DAS & 98 DAS \\
\hline fallow-fallow-maize (FFM) & $0.44 \mathrm{a}$ & $1.59 \mathrm{a}$ & $2.15 \mathrm{a}$ & $2.44 \mathrm{a}$ \\
\hline spearmint-spearmint-maize (SSM) & $0.34 \mathrm{a}$ & $1.32 \mathrm{~b}$ & $1.73 \mathrm{~b}$ & $2.21 \mathrm{a}$ \\
\hline peppermint-peppermint-maize (PPM) & $0.35 \mathrm{a}$ & $1.34 \mathrm{~b}$ & $1.84 \mathrm{ab}$ & $2.30 \mathrm{a}$ \\
\hline$F$ values & $5.393^{\mathrm{ns}}$ & $7.943 *$ & $7.372 *$ & $3.970 \mathrm{~ns}$ \\
\hline $\mathrm{LSD}_{5 \%}$ & - & 0.208 & 0.314 & - \\
\hline
\end{tabular}

${ }_{1}^{1}$ Days after sowing; ${ }^{*}, * *, * *:$ significantly different at $p<0.05, p<0.01$, and $p<0.001$, respectively; ns: not significantly different.

Table 4. Dry weight $\left(\mathrm{kg} \mathrm{ha}^{-1}\right)$ of maize plants as affected by the rotation system (fallow-fallow-maize (FFM), spearmint-spearmint-maize (SSM), peppermint-peppermint-maize (PPM)) at experimental sites A and B. Means at the same column followed by the same letter are not significantly different according to Fisher's Least Significant Difference (LSD) test $(p \leq 0.05)$.

\begin{tabular}{|c|c|c|c|c|}
\hline \multirow{2}{*}{ Treatments-Rotation System } & \multicolumn{4}{|c|}{ Dry Weight (kg ha $\left.{ }^{-1}\right)$-Site A } \\
\hline & 40 DAS $^{1}$ & 70 DAS & 84 DAS & 98 DAS \\
\hline fallow-fallow-maize (FFM) & $496 \mathrm{a}$ & 7298 a & $15,145 \mathrm{a}$ & $21,702 \mathrm{a}$ \\
\hline spearmint-spearmint-maize (SSM) & $368 \mathrm{~b}$ & $4841 \mathrm{~b}$ & $10,678 \mathrm{~b}$ & $15,297 b$ \\
\hline peppermint-peppermint-maize (PPM) & $375 \mathrm{~b}$ & $5028 \mathrm{~b}$ & $11,035 \mathrm{~b}$ & $16,249 \mathrm{~b}$ \\
\hline$F$ values & $23.160 * *$ & $26.283 * *$ & $21.857 * *$ & $23.098 * *$ \\
\hline $\mathrm{LSD}_{5} \%$ & 58.56 & 1619.93 & 2084.78 & 2823.55 \\
\hline \multirow{2}{*}{ Treatments-Rotation System } & \multicolumn{4}{|c|}{ Dry Weight (kg ha $\left.{ }^{-1}\right)$-Site B } \\
\hline & 40 DAS & 70 DAS & 84 DAS & 98 DAS \\
\hline fallow-fallow-maize (FFM) & $570 \mathrm{a}$ & $7195 \mathrm{a}$ & $14,145 \mathrm{a}$ & $19,844 \mathrm{a}$ \\
\hline spearmint-spearmint-maize (SSM) & $461 \mathrm{~b}$ & $5239 \mathrm{~b}$ & $11,652 \mathrm{~b}$ & $16,837 \mathrm{~b}$ \\
\hline peppermint-peppermint-maize (PPM) & $486 \mathrm{~b}$ & $5541 \mathrm{~b}$ & $12,152 b$ & $17,238 \mathrm{~b}$ \\
\hline$F$ values & $22.368^{* *}$ & $22.390 * *$ & 15.149 * & 12.912 ** \\
\hline $\mathrm{LSD}_{5 \%}$ & 47.67 & 873.80 & 1330.65 & 1783.89 \\
\hline
\end{tabular}

\footnotetext{
${ }^{1}$ Days after sowing; ${ }^{* * *}$ significantly different at $p<0.05$ and $p<0.01$, respectively.
}

\subsection{Yield and Yield Components}

The recorded yield components were also affected by the rotation system. Our data revealed that 1000-grain weight was significantly lower in the SSP and PPM rotation system than in the FFM system at both sites (Table 5). At site A, the values of 1000 -grain weight were reduced by $7.14 \%$ and $4.64 \%$ in the SSP and PPM rotation systems comparing to the FFM system, while at site B the negative effects of SSP and PPM rotation systems on 1000-grain weight were less severe ( $4.34 \%$ and $3.41 \%$ for SSM and PPM, respectively). Moreover, the ear length ranged from 16.70 to $22.57 \mathrm{~cm}$ and from 19.83 to $23.47 \mathrm{~cm}$ at sites A and B, respectively. Similarly to the 1000-grain weight, the highest values of ear length were recorded in the FFM rotation system, while ear length was significantly reduced when 
spearmint or peppermint were included in rotation systems. At both sites, there were no significant differences between the SSP and PPM rotation system for ear length.

Table 5. Yield $\left(\mathrm{kg} \mathrm{ha}^{-1}\right)$, ear length $(\mathrm{cm})$ and 1000-grain weight $(\mathrm{g})$ of maize plants as affected by the rotation system (fallow-fallow-maize (FFM), spearmint-spearmint-maize (SSM), peppermint-peppermint-maize (PPM)) at experimental sites A and B. Means at the same column followed by the same letter are not significantly different according to Fisher's Least Significant Difference (LSD) test $(p \leq 0.05)$.

\begin{tabular}{|c|c|c|c|}
\hline \multirow{2}{*}{ Treatments-Rotation System } & \multicolumn{3}{|c|}{ Site A } \\
\hline & 1000-Grain Weight (g) & Ear Length (cm) & Grain Yield $\left(\mathrm{kg} \mathrm{ha}^{-1}\right)$ \\
\hline fallow-fallow-maize (FFM) & $439.7 \mathrm{a}$ & $22.57 \mathrm{a}$ & 13,346 a \\
\hline spearmint-spearmint-maize (SSM) & $408.3 \mathrm{c}$ & $16.70 \mathrm{~b}$ & $10,200 \mathrm{~b}$ \\
\hline peppermint-peppermint-maize (PPM) & $419.3 \mathrm{~b}$ & $17.83 \mathrm{~b}$ & $10,967 \mathrm{~b}$ \\
\hline$F$ values & $37.507^{* *}$ & $60.951^{* * *}$ & $31.612 * *$ \\
\hline $\mathrm{LSD}_{5} \%$ & 10.237 & 1.565 & 1145.83 \\
\hline \multirow{2}{*}{ Treatments-Rotation System } & \multicolumn{3}{|c|}{ Site B } \\
\hline & 1000-Grain Weight (g) & Ear Length (cm) & Grain Yield $\left(\mathrm{kg} \mathrm{ha}^{-1}\right)$ \\
\hline fallow-fallow-maize (FFM) & $398.3 \mathrm{a}$ & $23.47 \mathrm{a}$ & 14,106 a \\
\hline spearmint-spearmint-maize (SSM) & $381.0 \mathrm{~b}$ & $19.83 \mathrm{~b}$ & $11,773 \mathrm{~b}$ \\
\hline peppermint-peppermint-maize (PPM) & $384.7 \mathrm{~b}$ & $20.23 \mathrm{~b}$ & $12,391 \mathrm{~b}$ \\
\hline$F$ values & $11.827 *$ & $32.087^{* *}$ & $24.479 * *$ \\
\hline $\mathrm{LSD}_{5 \%}$ & 10.430 & 1.381 & 959.19 \\
\hline
\end{tabular}

The grain yield ranged from 10,200 to $13,346 \mathrm{~kg} \mathrm{ha}^{-1}$ and from 11,773 to $14,106 \mathrm{~kg} \mathrm{ha}^{-1}$ at sites A and B, respectively. Differences in grain yield was observed among the rotation systems, while similar trends with the rest of the cited yield components were recorded regarding the effect of crop rotation system. The lowest grain yield was recorded in the PPM and SSM rotation systems. Moreover, at site A, the grain yield of maize was reduced by $23.57 \%$ and $17.82 \%$ in the SSM and PPM rotation systems, respectively comparing to the FFM system. Similar results were observed at site B where grain yield was reduced by $16.54 \%$ and $12.16 \%$ in the SSM and PPM rotation systems, respectively.

\subsection{Pearson Correlation Coefficients}

According to Pearson Correlation Coefficients, significant $(p<0.05, p<0.01, p<0.001)$ positive correlations were recorded among the tested parameters for both sites, although some parameters were not significantly correlated, especially at site B (Table 6). It worth's mentioning that correlation coefficients were positively correlated at $p>0.01$ for almost all the tested parameters at site A, while the highest values were recorded for ear length (EAR) and photosynthetic rate (PR) and ear length and stomatal conductance (SC). However, correlation coefficients were slightly lower at site B, whereas in several occasions no correlations were observed (e.g., SPAD and height, stomatal conductance and height, ear length and height and so forth). The differences between experimental sites highlights the effect of growing conditions on phenotypic expression of maize plants as well on unfolding yield potential. 
Table 6. Pearson correlation coefficients ${ }^{1}$ between the main maize parameters.

\begin{tabular}{ccccccccc}
\hline Parameters-Site A & H & SPAD & DW & PR & SC & EAR & GW & GY \\
\hline Height (H) & - & $0.883^{* *}$ & $0.812^{* *}$ & $0.919^{* * *}$ & $0.924^{* * *}$ & $0.901^{* * *}$ & $0.791^{*}$ & $0.859^{* *}$ \\
Chlorophyll content (SPAD) & - & - & $0.943^{* * *}$ & $0.910^{* * *}$ & $0.890^{* *}$ & $0.921^{* * *}$ & $0.892^{* *}$ & $0.824^{* *}$ \\
Dry weight (DW) & - & - & - & $0.870^{* *}$ & $0.863^{* *}$ & $0.919^{* * *}$ & $0.939^{* * *}$ & $0.848^{* *}$ \\
Photosynthetic rate (PR) & - & - & - & - & $0.964^{* * *}$ & $0.987^{* * *}$ & $0.891^{* *}$ & $0.961^{* * *}$ \\
Stomatal conductance (SC) & - & - & - & & - & $0.973^{* * *}$ & $0.899^{* * *}$ & $0.924^{* * *}$ \\
Ear length (EAR) & - & - & - & & - & - & $0.930^{* * *}$ & $0.952^{* * *}$ \\
1000-grain weight (GW) & - & - & - & - & - & - & - & $0.903^{* * *}$ \\
Grain yield (GY) & - & - & - & - & - & - & - & - \\
\hline Parameters-Site B & H & SPAD & DW & PR & SC & EAR & GW & GY \\
\hline Height (H) & - & $0.477^{\text {ns }}$ & $0.753^{*}$ & $0.687^{*}$ & $0.635^{\mathrm{ns}}$ & $0.484^{\mathrm{ns}}$ & $0.595^{\mathrm{ns}}$ & $0.876^{* *}$ \\
Chlorophyll content (SPAD) & - & - & $0.669^{*}$ & $0.812^{* *}$ & $0.880^{* *}$ & $0.857^{* *}$ & $0.737^{*}$ & $0.744^{*}$ \\
Dry weight (DW) & - & - & - & $0.789^{*}$ & $0.720^{* *}$ & $0.473^{\text {ns }}$ & $0.640^{\mathrm{ns}}$ & $0.818^{* *}$ \\
Photosynthetic rate (PR) & - & - & - & - & $0.946^{* * *}$ & $0.742^{*}$ & $0.771^{*}$ & $0.897^{* *}$ \\
Stomatal conductance (SC) & - & - & - & & - & $0.850^{* *}$ & $0.831^{* *}$ & $0.885^{* *}$ \\
Ear length (EAR) & - & - & - & & - & - & $0.871^{* *}$ & $0.726^{*}$ \\
1000-grain weight (GW) & - & - & - & - & - & - & - & $0.837^{* *}$ \\
Grain yield (GY) & - & - & - & - & - & - & - & - \\
\hline 1
\end{tabular}

${ }^{1} r$ was calculated using the linear equation. $n=9$. Significant at ${ }^{*} p<0.05,{ }^{* *} p<0.01,{ }^{* * *} p<0.001$. ns: not significant.

\section{Discussion}

Crop rotation is a very important cultivation practice for weed and pathogens control, while it is crucial in sustainable and organic farming systems since it allows for better use efficiency of the available resources while at the same time it helps to preserve soil fertility. However, before planning a crop rotation system several factors have to be considered including plant species interactions as well the effects of abiotic factors on cultivated plants. In this context, the present study was carried out in order to reveal possible allelopathic effects of spearmint and peppermint crops on maize plants when the latter was used as successive crop.

\subsection{Physiological Parameters}

Our results indicate that the inclusion of spearmint and peppermint in rotation systems significantly affect the physiological parameters of maize plants. The relative chlorophyll content (SPAD index values), stomatal conductance, and photosynthetic rate were significantly lower in the PPM and SSM rotation systems, revealing that the release of allelochemicals into soil from peppermint or spearmint residues (root, stems and leaves) negatively affect plant photosynthesis and transpiration, resulting in decreased plant growth and yield as discussed below. According to Mahdavikia and Saharkhiz [26], phenolic compounds such as ellagic acid, hesperidin, sinapic acid, and trans-ferulic acid which are present in water extracts of peppermint could be responsible for reduced germination and seedling growth of tomato plants through the induction of oxidative stress. The allelopathic activity of phenolic acids has been suggested by Fu et al. [27] who tested the toxic effects of various phenolic acids on Rhododendron delavayi seedlings and observed variable effects depending on the phenolic acid and the tested concentration. The allelopathic potential of Mentha crops has been also tested through the use of their essential oils against weeds. In this context, Argyropoulos et al. [20] reported that the essential oil of spearmint exhibited allelopathic activity and affected the seed germination of various weeds (e.g., Amaranthus retroflexus L., Echinochloa crus-galli (L.) P. Beauv., Oryza sativa L., Portulaca oleracea L., and Setaria verticillata (L.) P. Beauv.), while Synowiec et al. [28] observed significant phytotoxic effects of peppermint essential oil against several weed species.

Regarding the allelopathic effects of Mentha species on crop physiological parameters, Skrzypek et al. [29] reported that the aqueous extracts from peppermint leaves decreased the chlorophyll a content in sunflower leaves due to damage in photosynthetic apparatus. In another study, Oyerinde et al. [30] observed that the aqueous extracts from stems of tree marigold (Tithonia diversifolia (Hemsl.) A. Gray) caused a reduction in total chlorophyll content in maize plants, however, they also reported that these 
effects may differ depending on maize growth stage being either inhibitory or stimulatory. In contrast, Mahdavikia and Saharkhiz [26] reported that water extracts from the aerial parts of peppermint caused oxidative stress in tomato plants but had no impact on relative chlorophyll content (SPAD values) suggesting that the high levels of reactive oxygen species were responsible for reduced seedling growth. Additionally, the allelochemicals that above- and below-ground plant parts contain may affect the photosynthesis and transpiration processes thus resulting in reduced plant growth [30,31]. Phenolic compounds are considered as compounds with allelopathic potential since ferulic acid, chlorogenic acid, and protocatechuic acid have been reported to decrease photosynthetic rate and/or stomatal conductance of Rhododendron delavayi Franch. seedlings grown in pots [27], while Zhou et al. [32] reported that the application of leaf litter of English walnut (Juglans regia L.) and the released allelochemicals caused a reduction in stomatal conductance, transpiration, and net photosynthetic rates of spinach (Spinacia oleracea L.).

\subsection{Maize Growth}

The height and dry biomass of maize plants was significantly lower in the PPM and SSM rotation systems, whereas there were no significant differences between these rotation systems. As discussed before, the reduction of photosynthetic rate in SSM and PPM treatments resulted in a decrease of maize height and dry biomass. This is supported by the results of correlation analysis (Table 6), since the maize dry biomass showed a positive and significant correlation with photosynthetic rate $(r=0.870$, $p<0.01$ and $r=0.789, p<0.05$ at site $\mathrm{A}$ and $\mathrm{B}$, respectively). Thus, any reductions in maize height and biomass in PPM and SSM treatment could be associated with decreased photosynthetic rate and inhibition of biosynthetic processes due to the allelopathic activity of peppermint and spearmint against maize plants. Although such effects of peppermint and spearmint on successive crops growth are rarely reported, several studies suggest the inhibitory effects of essential oils and plant extracts of Mentha species against weeds [20,23]. Moreover, according to Skrzypek et al. [29] the aqueous extracts of peppermint leaves reduced germination of sunflower seeds (Helianthus annuus L.), while Mahdavikia and Saharkhiz [26] reported that water extracts from the aerial parts of peppermint decreased the leaf area and dry biomass of tomato seedlings. A similar effect was reported by Mahdavikia et al. [31] who found that the growth of radish seedlings (leaf area and dry weight) was inhibited by the peppermint water extracts. Türker et al. [33] suggested that allelopathic effects may start even during germination, since plant extracts from several species including Mentha longfolia (L.) Huds. suppressed germination of maize seeds. In contrast, Ulbrich et al. [34] reported stimulatory effects of Mentha $\times$ piperita essential oils on Brassica oleraceae seedlings when an intercropping system was applied, although they mentioned that when pure compounds were applied no effects were observed. These findings need further investigation to reveal whether the combined effect of volatile components or other compounds excreted from Mentha plants are responsible for the allelopathic activity. To the best of our knowledge, there are no reports regarding the effects of peppermint and spearmint on succeeding crops when crop rotation system is applied. Similar to our results, Narwal et al. [35] observed that sunflower as preceding crop caused a reduction in plant height and dry biomass on cotton crop. Additionally, spring and winter wheat growth was inhibited when following a mustard (Brassica juncea L.) crop [36]. On the contrary, it is also reported that the inclusion of allelopathic crops in a crop rotation system has not always negative effects and may improve plant growth of subsequent crops. For example, in a recent study Farooq et al. [16] reported that the inclusion of sorghum in a wheat-rice rotation program improved rice growth (e.g., height) due to weed suppression.

Allelopathic efficiency of allelochemicals may be affected by various factors including growing conditions and plant species. Our results demonstrated that the allelopathic activity of spearmint and peppermint against maize plants was stronger at site $\mathrm{A}$ than that at site $\mathrm{B}$. This finding may be due to the differences between the two sites on soil texture and climatic conditions. The soil at site B was heavier (high clay content) in comparison to soil of site A and had higher sorption capacity of allelochemicals released by peppermint or spearmint residues; thus the concentrations of allelochemicals in the soil and 
the allelopathic activity of spearmint and peppermint should be expected to be higher at site A than site B. According to several studies, the allelochemicals (e.g., benzoic acid, p-hydroxybenzoic acid, cinnamic acid, and umbelliferone) are absorbed onto soil particles [37-40], while their concentrations in soil water affect their phytotoxic and allelopathic activity [41]. In a previous study, Inderjit and Bhowmik [38] observed that the sorption of benzoic acid, a compound which is considered a model allelopathic substance, was higher in soils with high clay and organic matter content. The biological activity of allelochemicals in soil is also influenced by the process of leaching with compounds such as $p$-coumaric and $p$-hydroxybenzoic acids showing the lowest leachability and thus the highest bioavailability [42]. Therefore, it could be assumed that the reduction of allelopathic activity of allelochemicals at site $\mathrm{B}$ might be due to the higher precipitation level at this site which was 2.38 -fold greater than site A and thus the leaching and downwards movement of allelochemicals in soil at site B was higher in comparison to that in site A.

\subsection{Yield and Yield Components}

Apart from physiological parameters and plant growth, the yield components of maize were also affected by the implemented rotation system. Our data revealed that 1000-grain weight was significantly lower in the SSP and PPM rotation system than the FFM system at both experimental sites. In contrast to our study, Farooq et al. [16] observed that the 1000-grain weight of rice crop was higher in the wheat-sorghum-dry seeded aerobic rice (DSAR) rotation than that in the wheat-fallow-DSAR rotation. However, these differences could be attributed to differences in plant species, since sorghum water extracts and composts had a beneficial effect on rice plants. Differences among the rotation systems were also observed in terms of grain yield and the lowest grain yield was recorded in the PPM and SSP rotation systems. This yield reduction could be due to the release of certain allelochemicals by peppermint and spearmint through root exudates or after decomposition of plant residuals which retarded the growth of maize plants. This assumption is supported by the results of correlation analysis between the studied parameters, where grain yield showed a positive and significant correlation with aboveground biomass ( $r=0.848, p<0.01$ and $r=0.818, p<0.01$ at site A and B, respectively). Similarly to our results, Vishwajith et al. [43] found that the seed yield of mungbean (Vigna radiata L. Wilczek) was lower in a sunflower-mungbean rotation system than that of fallow-mungbean, revealing the allelopathic effects of sunflower on the subsequent mungbean crop. In contrast, Cheema et al. [44] reported that grain yield of maize crop was increased in the sorghum mulch treatment due to reduced weed-crop interference that resulted in increased leaf area of maize plants. These differences in the literature highlight the importance of further research regarding the combination of plants in rotation programs as well as the growing conditions which may affect the plant growth and the efficacy of allelochemicals.

\section{Conclusions}

The results of the present study indicate that the inclusion of spearmint and peppermint in crop rotations systems significantly affected plant growth of maize. Both height and biomass of maize plants were significantly lower in the PPM and SSM rotation systems in comparison to FFM rotation. Our results have also revealed that several physiological characteristics (chlorophyll content, stomatal conductance, and photosynthetic rate) were influenced by the implemented crop rotation system. Photosynthetic rate of maize plants was significantly reduced in rotation systems where spearmint and peppermint were included (SSM and PPM, respectively) in comparison to control treatment (FFM system), while similar negative effects were also observed on maize grain yield. This is in accordance with correlation coefficient values of our study where photosynthetic rate is positively correlated with plant height and yield components, therefore any adverse effects on photosynthesis are reflected to plant growth and yield of maize. In conclusion, the inclusion of allelopathic crops in crop rotation systems seems to be a promising tool for weed control in sustainable and organic farming systems, the possible impacts on successive crops have also to be considered since inhibitory effects could be 
observed. Despite the positive effects of such a crop rotation system that may arise in terms of weed control and the high added value of the final products of peppermint and spearmint crops, the negative effects on the growth and yield of the successive crops (in our case maze) have to be taken into account. On that ground, further studies are needed in order to examine the effects of crops with allelopathic potential on the growth and yield of other successive crops and the overall economic impact, as well as analytical studies to identify specific compounds that are responsible for such adverse effects and agronomic means and growing conditions that may regulate their production.

Author Contributions: A.K. conceived and designed the research, supervised the field measurements at the experimental farm of University of Thessaly at Velestino site, made the field measurements at Domokos site, analyzed the data and wrote the draft manuscript and edited the final version of the manuscript; S.P. made the field measurements at Domokos site, wrote and edited the manuscript; C.K. and A.A. made the field measurements at the experimental farm of University of Thessaly at Velestino site. All authors approved the manuscript.

Funding: This research received no external funding.

Acknowledgments: The authors would like to thank Spyridon Souipas for providing technical support for the experiment at the experimental farm of University in Velestino.

Conflicts of Interest: The authors declare no conflict of interest.

\section{References}

1. Migliorini, P.; Wezel, A. Converging and diverging principles and practices of organic agriculture regulations and agroecology. A Review. Agron. Sustain. Dev. 2017, 37, 1-18. [CrossRef]

2. Ntatsi, G.; Karkanis, A.; Yfantopoulos, D.; Pappa, V.; Konosonoka, I.H.; Travlos, I.; Bilalis, D.; Bebeli, P.; Savvas, D. Evaluation of the field performance, nitrogen fixation efficiency and competitive ability of pea landraces grown under organic and conventional farming systems. Arch. Agron. Soil Sci. 2019, 65, $294-307$. [CrossRef]

3. Ntatsi, G.; Karkanis, A.; Yfantopoulos, D.; Olle, M.; Travlos, I.; Thanopoulos, R.; Bilalis, D.; Bebeli, P.; Savvas, D. Impact of variety and farming practices on growth, yield, weed flora and symbiotic nitrogen fixation in faba bean cultivated for fresh seed production. Acta Agric. Scand. Sect. B Soil Plant Sci. 2018, 68, 619-630. [CrossRef]

4. Karkanis, A.; Ntatsi, G.; Lepse, L.; Fernández, J.A.; Vågen, I.M.; Rewald, B.; Alsina, I.; Kronberga, A.; Balliu, A.; Olle, M.; et al. Faba Bean cultivation-Revealing novel managing practices for more sustainable and competitive European cropping systems. Front. Plant Sci. 2018, 9, 1-14. [CrossRef]

5. Sánchez-Navarro, V.; Zornoza, R.; Faz, Á.; Fernández, J.A. Comparing legumes for use in multiple cropping to enhance soil organic carbon, soil fertility, aggregates stability and vegetables yields under semi-arid conditions. Sci. Hortic. 2019, 246, 835-841. [CrossRef]

6. Uzoh, I.M.; Igwe, C.A.; Okebalama, C.B.; Babalola, O.O. Legume-maize rotation effect on maize productivity and soil fertility parameters under selected agronomic practices in a sandy loam soil. Sci. Rep. 2019, 9, 1-9. [CrossRef]

7. Park, S.E.; Webster, T.J.; Horan, H.L.; James, A.T.; Thorburn, P.J. A legume rotation crop lessens the need for nitrogen fertiliser throughout the sugarcane cropping cycle. Field Crop. Res. 2010, 119, 331-341. [CrossRef]

8. McDonald, G.K.; Peck, D. Effects of crop rotation, residue retention and sowing time on the incidence and survival of ascochyta blight and its effect on grain yield of field peas (Pisum sativum). Field Crop. Res. 2009, 111, 11-21. [CrossRef]

9. Conner, R.L.; Gillard, C.L.; Mcrae, K.B.; Hwang, S.F.; Chen, Y.Y.; Hou, A.; Penner, W.C.; Turnbull, G.D. Survival of the bean anthracnose fungus (Colletotrichum lindemuthianum) on crop debris in Canada. Can. J. Plant Pathol. 2019, 41, 209-217. [CrossRef]

10. Wozniak, A.; Soroka, M. Effect of crop rotation and tillage system on the weed infestation and yield of spring wheat and on soil properties. Appl. Ecol. Environ. Res. 2018, 16, 3087-3096. [CrossRef]

11. Narwal, S.S. Weed management in rice: Wheat Rotation by allelopathy. CRC Crit. Rev. Plant Sci. 2000, 19, 249-266. [CrossRef]

12. Mamolos, A.; Kalburtji, K. Significance of allelopathy in crop rotation. J. Crop Prod. 2001, 4, $197-218$. [CrossRef] 
13. Khanh, T.D.; Chung, M.I.; Xuan, T.D.; Tawata, S. Cropping and forage systems/crop ecology/organic farming the exploitation of crop allelopathy in sustainable agricultural production. J. Agron. Crop Sci. 2005, 191, 172-184. [CrossRef]

14. Nichols, V.; Verhulst, N.; Cox, R.; Govaerts, B. Weed dynamics and conservation agriculture principles: A Review. Field Crop. Res. 2015, 183, 56-68. [CrossRef]

15. Rehman, S.; Shahzad, B.; Bajwa, A.A.; Hussain, S.; Rehman, A.; Cheema, S.A.; Abbas, T.; Ali, A.; Shah, L.; Adkins, S.; et al. Utilizing the allelopathic potential of Brassica species for sustainable crop production: A Review. J. Plant Growth Regul. 2019, 38, 343-356. [CrossRef]

16. Farooq, M.; Nawaz, A.; Ahmad, E.; Nadeem, F.; Hussain, M.; Siddique, K.H.M. Using Sorghum to suppress weeds in dry seeded aerobic and puddled transplanted rice. Field Crop. Res. 2017, 214, 211-218. [CrossRef]

17. Liu, S.; Wu, F.; Wen, X. Allelopathic effects of root exudates of chinese onion on tomato growth and the pathogen Fusarium oxysporum (Sch1) f.sp. lycopersici. Allelopath. J. 2013, 31, 387-403.

18. Mominul Islam, A.K.M.; Kato-Noguchi, H. Allelopathic potential of five labiatae plant species on barnyard grass (Echinochloa crus-galli). Aust. J. Crop Sci. 2013, 7, 1369-1374.

19. Karkanis, A.; Lykas, C.; Liava, V.; Bezou, A.; Petropoulos, S.; Tsiropoulos, N. Weed Interference with peppermint (Mentha $\times$ piperita L.) and spearmint (Mentha spicata L.) crops under different herbicide treatments: Effects on Biomass and essential oil yield. J. Sci. Food Agric. 2018, 98, 43-50. [CrossRef]

20. Argyropoulos, E.I.; Eleftherohorinos, I.G.; Vokou, D. In vitro evaluation of essential oils from Mediterranean aromatic plants of the lamiaceae for weed control in tomato and cotton crops. Allelopath. J. 2008, 22, 69-78.

21. Azizi, M.; Mosavi, A.; Nazdar, T. Extraction methods affect allelopathic activity of peppermint and thyme extracts on weed seed germination. Acta Hortic. 2008, 767, 97-104. [CrossRef]

22. Azirak, S.; Karaman, S. Allelopathic effect of some essential oils and components on germination of weed species. Acta Agric. Scand. Sect. B Soil Plant Sci. 2008, 58, 88-92. [CrossRef]

23. Chalkos, D.; Kadoglidou, K.; Karamanoli, K.; Fotiou, C.; Pavlatou-Ve, A.S.; Eleftherohorinos, I.G.; Constantinidou, H.I.A.; Vokou, D. Mentha spicata and Salvia fruticosa composts as soil amendments in tomato cultivation. Plant Soil 2010, 332, 495-509. [CrossRef]

24. Islam, A.K.M.M.; Kato-Noguchi, H. Mentha sylvestris: A potential allelopathic medicinal plant. Int. J. Agric. Biol. 2013, 15, 1313-1318.

25. Naeem, M.; Nisar, U.; Khalid, F.; Mehmood, A.; Ali, H.H. Quantifying allelopathic effect of rapeseed on germination and seedling growth of maize under different salinity levels. Zemdirb. Agric. 2017, 104, $259-266$. [CrossRef]

26. Mahdavikia, F.; Saharkhiz, M.J. Secondary metabolites of peppermint change the morphophysiological and biochemical characteristics of tomato. Biocatal. Agric. Biotechnol. 2016, 7, 127-133. [CrossRef]

27. Fu, Y.H.; Quan, W.X.; Li, C.C.; Qian, C.Y.; Tang, F.H.; Chen, X.J. Allelopathic effects of phenolic acids on seedling growth and photosynthesis in Rhododendron delavayi Franch. Photosynthetica 2019, 57, 377-387. [CrossRef]

28. Synowiec, A.; Halecki, W.; Wielgusz, K.; Byczyńska, M.; Czaplicki, S. Effect of fatty acid methyl esters on the herbicidal effect of essential oils on corn and weeds. Weed Technol. 2017, 31, 301-309. [CrossRef]

29. Skrzypek, E.; Repka, P.; Stachurska-Swakon, A.; Barabasz-Krasny, B.; Mozdzen, K. Allelopathic effect of aqueous extracts from the leaves of peppermint (Mentha $\times$ piperita L.) on Selected physiological processes of common sunflower (Helianthus annuus L.). Not. Bot. Horti Agrobot. Cluj Napoca 2015, 43, 335-342. [CrossRef]

30. Oyerinde, R.O.; Otusanya, O.O.; Akpor, O.B. Allelopathic Effect of Tithonia diversifolia on the germination, growth and chlorophyll contents of maize (Zea mays L.). Sci. Res. Essays 2009, 4, 1553-1558.

31. Mahdavikia, F.; Saharkhiz, M.J.; Karami, A. Defensive response of radish seedlings to the oxidative stress arising from phenolic compounds in the extract of peppermint (Mentha $\times$ piperita L.). Sci. Hortic. (Amsterdam) 2017, 214, 133-140. [CrossRef]

32. Zhou, G.; Hu, T.; Wu, Z.; Chen, H.; Luo, J.; Li, W. Effects of Juglans Regia leaf litter decomposition on growth and physiological characteristics of spinach (Spinacia oleracea). Chin. J. Appl. Environ. Biol. 2015, 21, 777-782.

33. Türker, M.; Battal, P.; Ağar, G.; Güllüce, M.; Şahin, F.; Erez, M.E.; Yildirim, N. Allelopathic effects of plants extracts on physiological and cytological processes during maize seed germination. Allelopath. J. 2008, 21, 273-286.

34. Ulbrich, A.; Kahle, H.; Krämer, P.; Schulz, M. Mentha $\times$ piperita volatiles promote Brassica oleracea-A pilot study for sustainable vegetable production. Allelopath. J. 2018, 43, 93-104. [CrossRef] 
35. Narwal, S.S.; Singh, T.; Hooda, J.S.; Kathuria, M.K. Allelopathic effects of sunflower on succeeding summer crops. I. Field studies and bioassays. Allelopath. J. 1999, 6, 35-48.

36. Moyer, J.R.; Blackshaw, R.E.; Doram, R.C.; Huang, H.C.; Entz, T. Effect of previous crop and herbicides on weed growth and wheat yield. Can. J. Plant Sci. 2011, 85, 735-746. [CrossRef]

37. Dalton, B.R.; Blum, U.; Weed, S.B. Plant Phenolic acids in soils: Sorption of ferulic acid by soil and soil components sterilized by different techniques. Soil Biol. Biochem. 1989, 21, 1011-1018. [CrossRef]

38. Inderjit; Bhowmik, P.C. Sorption of benzoic acid onto soil colloids and its implications for allelopathy studies. Biol. Fertil. Soils 2004, 40, 345-348. [CrossRef]

39. Real, M.; Gámiz, B.; López-cabeza, R.; Celis, R. Sorption, persistence, and leaching of the allelochemical umbelliferone in soils treated with nanoengineered sorbents. Sci. Rep. 2019, 9, 1-11. [CrossRef]

40. Wang, Y.; Wang, H.; Jiang, Y. Sorption and retention of phenolic acids in soil poplar plantation in eastern china. In Proceedings of the 2011 International Conference on Remote Sensing, Environment and Transportation Engineering, Nanjing, China, 24-26 June 2011; pp. 7836-7840. [CrossRef]

41. Kobayashi, K. Factors Affecting phytotoxic activity of allelochemicals in soil. Weed Biol. Manag. 2004, 4, 1-7. [CrossRef]

42. Xiao, Z.; Le, C.; Xu, Z.; Gu, Z.; Lv, J.; Shamsi, I.H. Vertical leaching of allelochemicals affecting their bioactivity and the microbial community of soil. J. Agric. Food Chem. 2017, 65, 7847-7853. [CrossRef] [PubMed]

43. Vishwajith; Halagalimath, S.P.; Ganajaxi, M. Allelopathic effects of sunflower on succeeding mungbean (Vigna radiata L. Wilczek) crop. Allelopath. J. 2017, 42, 37-48. [CrossRef]

44. Cheema, Z.; Khaliq, A.; Saeed, S. Weed control in maize (Zea mays L.) through Sorghum alllelopathy. J. Sustain. Agric. 2004, 23, 73-86. [CrossRef]

(C) 2019 by the authors. Licensee MDPI, Basel, Switzerland. This article is an open access article distributed under the terms and conditions of the Creative Commons Attribution (CC BY) license (http://creativecommons.org/licenses/by/4.0/). 